\title{
Endoscopic negative pressure therapy for a broad rectal fistula using pull-through open-pore film and polyurethane foam drains
}

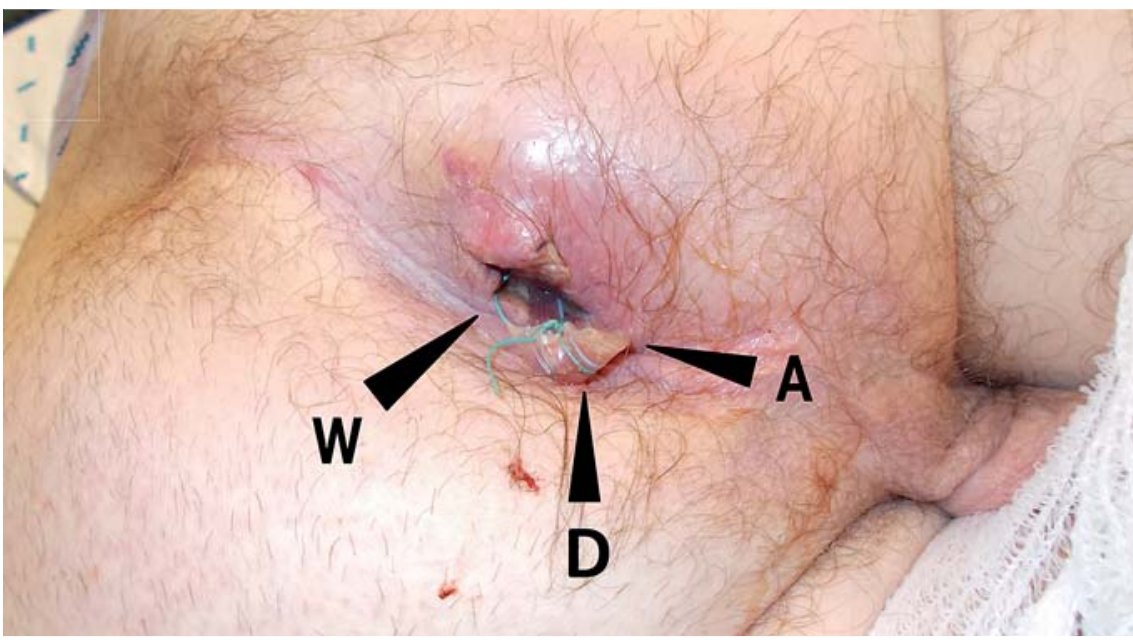

- Fig. 1 Photograph of the external appearance on the first postoperative day showing the wound opening $(W)$, anus $(A)$, and loop drain (D).
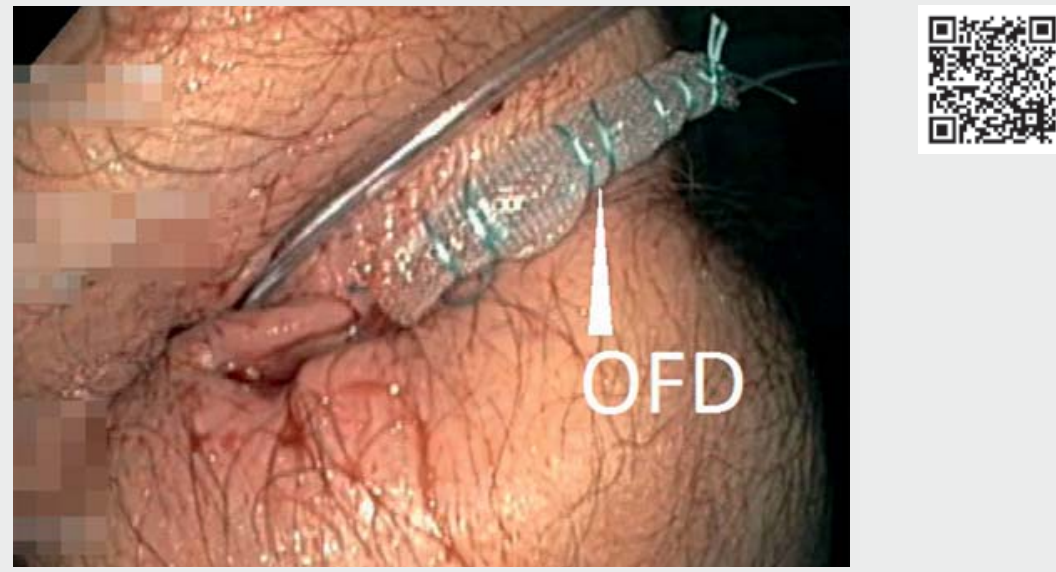

$\checkmark$ Video 1 The pull-through method being used to insert and replace the drainage elements for endoscopic negative pressure therapy in a patient with a broad anal fistula.

A 63-year-old man presented with a large acute pararectal abscess, with a broad suprasphincter fistula. Initial emergency surgical treatment consisted of opening the abscess and insertion of a loop drain ( Fig. 1). Further therapy was performed by endoscopic negative pressure therapy (ENPT), sequentially using open-pore foam drains (OPDs) and open-pore film drains (OFDs) in a novel pull-through technique [1-3].

The pull-through OPD technique was as follows: an open-pore polyurethane foam was knotted onto the distal end of an 18-Fr nasogastric tube (NGT), which was connected to another 12-Fr NGT, thereby holding the drainage element in the middle of the two tubes. The pull-

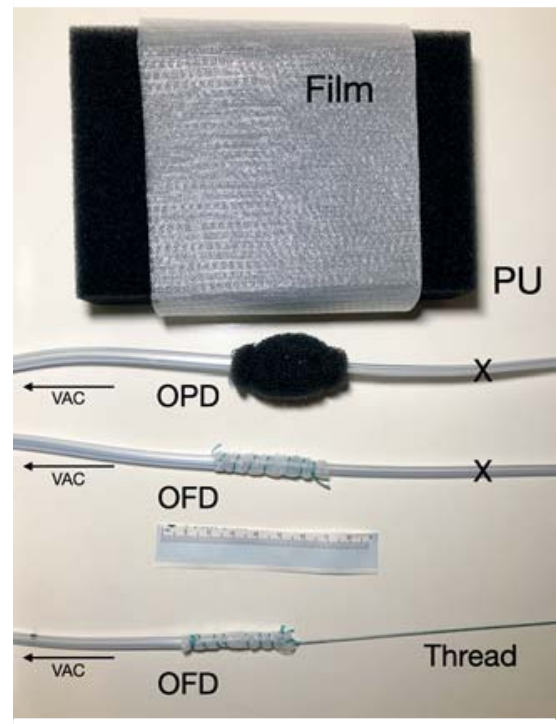

- Fig. 2 Photograph of the materials used for open-pore drainage showing the polyurethane foam (PU) and thin doublelayered drainage film, which were used to construct three different pull-through drains: an open-pore PU drain (OPD), an open-pore film drain (OFD), and an OFD with a thread for the final pull-through maneuver. VAC, vacuum suction; $X$, the point where one channel of the pullthrough drain was blocked to allow the application of negative pressure.

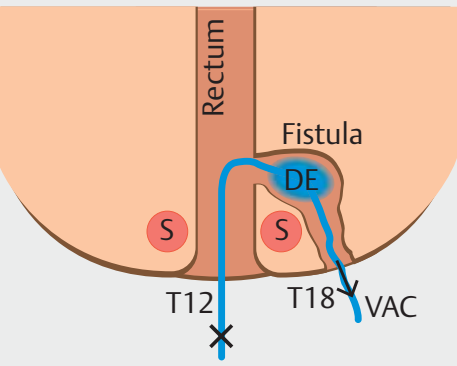

-Fig. 3 Schema showing the pullthrough drainage technique. DE, drainage element; S, sphincter ani, T12, 12-Fr drainage tube; $\mathrm{T} 18,18-\mathrm{Fr}$ drainage tube; VAC, vacuum suction; $X$, the point where one channel of the pullthrough drain was blocked to allow the application of negative pressure. 


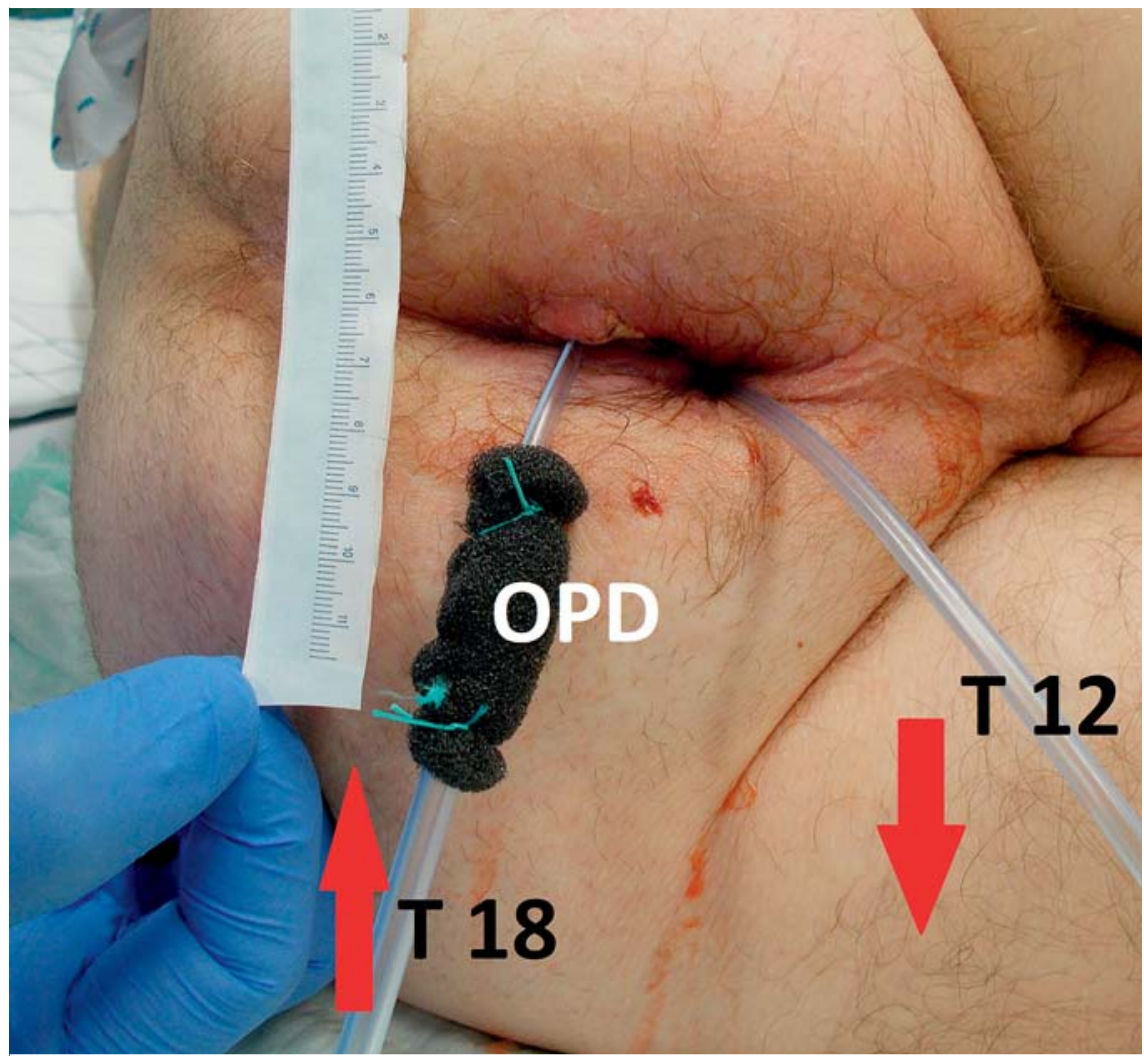

- Fig. 4 Photograph of the pull-through maneuver being performed for a pull-through open-pore polyurethane foam drain (OPD), which was constructed using a $12-\mathrm{Fr}$ drainage tube (T12) and a second 18- $\mathrm{Fr}$ tube (T18). The red arrows indicate the direction of pull. through OFD technique was as follows: the distal end of the 18-Fr NGT was covered with a thin, open-pore, doublelayered drainage film (Suprasorb CNP Drainage Film; Lohmann \& Rauscher, Germany), and again a 12 -Fr NGT was connected to the distal end of the tube ( Fig.2). With OPDs, the size of the foam is adjustable to bigger wound cavities, whereas an OFD has a small diameter $(4-6 \mathrm{~mm})$ and is less adhesive to the adjacent tissue [4].

ENPT was started by replacing the initial loop drain with an OPD using a pullthrough technique ( $\triangleright$ Video 1$)$. The drainage element was placed in the wound cavity. The external wound was surgically closed. The end of the tube was passed through the fistula, exiting the body through the anus, where negative pressure of $-125 \mathrm{mmHg}$ (Activac, $\mathrm{KCl}$, USA) was established ( $\boldsymbol{F} \mathbf{F i g . 3}$ ).
At intervals of 3-4 days thereafter, the wound was re-opened, with the OPD being easily replaced using a pullthrough maneuver ( $\mathbf{F i g} \mathbf{4}$ ). After 14 days (four changes), the wound cavity had shrunk to a channel and ENPT was then continued using the small-bore pull-through OFD (two changes in 7 days). For the last cycle, a pull-through OFD with a thread was used.

The ENPT was completed after 21 days, and was followed by 7 days of rinsing with an enema twice a day [5]. Following this, the broad rectal fistula and large abscess had healed completely ( $\bullet$ Fig. $\mathbf{5}$ ), with sphincter function being unimpaired and a colostomy having been avoided.

Endoscopy_UCTN_Code_TTT_1AQ_2AG

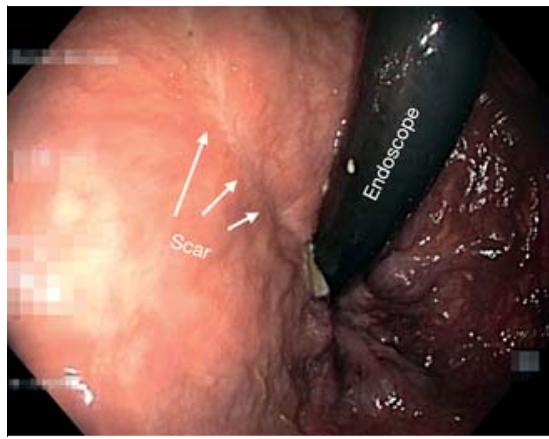

- Fig. 5 Endoscopic view of the healed fistula with a slight scar visible.

Competing interests

Gunnar Loske is a consultant for Lohmann \& Rauscher $\mathrm{GmbH} \&$ Co.KG. The remaining authors declare that they have no conflict of interest.

The authors

Johannes Müller, Anna-Maria Goerdt, Christian T. Müller, Gunnar Loske ${ }^{\circ}$ Department for General, Abdominal, Thoracic and Vascular Surgery, Katholisches Marienkrankenhaus Hamburg gGmbH, Hamburg, Germany

\section{Corresponding author}

\section{Johannes Müller, MD}

Katholisches Marienkrankenhaus Hamburg $\mathrm{gGmbH}$, Department for General,

Abdominal, Thoracic and Vascular Surgery, Alfredstrasse 9, 22087 Hamburg, Germany mueller21.ach@marienkrankenhaus.org

\section{References}

[1] Fischer A, Thimme R, Hopt UT et al. Twosided sponge (TSS) treatment: Description of a novel device and technique for endoscopic vacuum treatment (EVT) in the upper gastrointestinal tract Endosc Int Open 2016 4: E937-E940

[2] Loske G, Liedke M, Schlöricke E et al. Endoscopic negative-pressure therapy for duodenal leakage using new open-pore film and polyurethane foam drains with the pullthrough technique. Endoscopy 2017; 49: 300-302 
[3] Rucktaeschel F, Liedtke M, Schlöricke E et al. Gastroduodenal anastomotic insufficiency: pull-through technique for endoscopic negative pressure therapy with new types of open-pore drains. Endoscopy 2019; 51: $85-$ 87

[4] Loske G, Schorsch T, Rucktaeschel F et al. Open-pore film drainage (OFD): a new multipurpose tool for endoscopic negative pressure therapy (ENPT). Endosc Int Open 2018; 06: 865-871

[5] Kantowski M, Kunze A, Bellon E et al. Improved colorectal anastomotic leakage healing by transanal rinsing treatment after endoscopic vacuum therapy using a novel patient-applied rinsing catheter. Int J Colorectal Dis 2020; 35: 109-117

\section{Bibliography}

Endoscopy 2022; 54: E324-E326

DOI 10.1055/a-1519-6825

ISSN 0013-726X

published online 9.7.2021

(c) 2021. Thieme. All rights reserved.

Georg Thieme Verlag KG, Rüdigerstraße 14,

70469 Stuttgart, Germany

\section{ENDOSCOPY E-VIDEOS}

https://eref.thieme.de/e-videos

回局 Endoscopy E-Videos is an open access online section, 回梠: reporting on interesting cases and new techniques in gastroenterological endoscopy. All papers include a high quality video and all contributions are freely accessible online. Processing charges apply (currently EUR 375), discounts and wavers acc. to HINARI are available.

This section has its own submission website at

https://mc.manuscriptcentral.com/e-videos 